\title{
Pengaruh Lokasi Zeolit Alam Bayah terhadap Adsorpsi Amonium: Studi Kinetika dan Kesetimbangan
}

\section{The Effect of Mine Locations of Bayah Natural Zeolites on Ammonium Adsorption: A Kinetic and Equilibrium Study}

\author{
MOHAMAD HAKIKI ${ }^{1}$, MOHAMAD MAKIYI' ${ }^{1}$, NURYOTO ${ }^{1,2}$, RAHMAYETTY $^{1,2}$, INDAR KUSTININGSIH ${ }^{1,2}$, \\ TEGUH KURNIAWAN ${ }^{1,2^{*}}$ \\ 1Jurusan Teknik Kimia, Fakultas Teknik, Universitas Sultan Ageng Tirtayasa \\ Jl. Jend Sudirman Km.3, Cilegon, 42435, Indonesia \\ ${ }^{2}$ Program Studi Magister Teknik Kimia, Pascasarjana, Universitas Sultan Ageng Tirtayasa \\ Jl. Raya Jakarta Km.4 Pakupatan, Serang, 42122, Indonesia \\ *Email: teguh@untirta.ac.id
}

\begin{abstract}
Household waste is one of the most significant contributors to wastewater that can pollute the environment, one of which is ammonium pollution. Ammonium pollution can be reduced by natural zeolite by using the adsorption method. This research aims to utilize natural zeolite as an adsorbent that can reduce ammonium levels in wastewater, determine which natural zeolite has the most significant adsorption power from 4 locations, determine natural zeolite characterization of Bayah. This study is also to create a model equilibrium equations and reaction kinetics from the adsorption method. The method used is the adsorption method, X-ray diffraction (XRD), Scanning Electron Microscope (SEM), and Brunauer-Emmett-Teller (BET). This study's results were that natural zeolites location 4 could adsorb 99.25\% of ammonium and showed the highest adsorption capacity of ammonium. Characterization using $X R D$ analysis obtained the types of zeolite mordenite, clinoptilolite, quartz, and heulandite. The surface area of Bayah natural zeolite in the 4th location is $46 \mathrm{~m}^{2} / \mathrm{g}$. The suitable equilibrium model for the adsorption of ammonium by natural zeolites is the Freundlich model. The most suitable adsorption kinetics model for the adsorption of ammonium by Bayah natural zeolites is the pseudo-first-order model.
\end{abstract}

Keywords: household waste, ammonium, eutrophication, natural zeolites

\begin{abstract}
ABSTRAK
Limbah rumah tangga adalah salah satu penyumbang limbah cair terbesar yang dapat mencemari lingkungan salah satunya pencemaran amonium. Pencemaran amonium dapat dikurangi dengan zeolit alam dengan menggunakan metode adsorpsi. Tujuan dari penelitian ini adalah menentukan zeolit alam yang memiliki daya adsorpsi terbesar dari 4 lokasi berbeda, melakukan karakterisasi zeolit alam Bayah, dan memodelkan persamaan kesetimbangan dan kinetika reaksi adsorpsi amonium. Karakterisasi zeolit dilakukan dengan analisis X-ray diffraction (XRD), Scanning Electron Microsope (SEM), dan luas permukaan material menggunakan model Brunauer-Emmett-Teller (BET). Hasil dari penelitian ini adalah zeolit alam lokasi 4 memiliki kapasitas adsorpsi amonium paling besar, yaitu 9,25\%. Adapun kapasitas adsorpsi amonium yang paling besar ditunjukkan oleh zeolit alam Bayah lokasi 4. Analisis XRD menunjukkan bahwa seluruh zeolit Bayah merupakan zeolit bertipe mordenit, klinoptilolit, dan heulandit dengan fasa pengotor quartz. Luas permukaan zeolit alam Bayah lokasi 4 sebesar $46 \mathrm{~m}^{2} / \mathrm{g}$. Model kesetimbangan yang sesuai untuk adsorpsi amonium oleh zeolit alam Bayah yaitu model Freundlich. Model kinetika adsorpsi yang paling sesuai untuk adsorpsi amonium oleh zeolit alam Bayah yaitu model kuasi orde satu.
\end{abstract}

Kata Kunci: limbah rumah tangga, amonium, eutrofikasi, zeolit alam

\section{PENDAHULUAN}

\subsection{Latar Belakang}

Kementerian Lingkungan Hidup dan Kehutanan (KemenLHK) menyatakan bahwa pada tahun 2020 sebanyak $82 \%$ sungai di perkotaan tercemar berat akibat buangan air limbah rumah tangga(1). Pencemaran air tersebut dapat menyebabkan air sungai menjadi berbau busuk, berwarna pekat, dan bahkan merusak ekosistem di dalamnya. Limbah rumah tangga umumnya mengandung komponen organik yang mudah terdegradsi oleh mikroorganisme sehingga menimbulkan bau yang tidak sedap dan mengakibatkan perubahan drastis pada $\mathrm{pH}$ air. Akibat dari penguraian limbah organik yang mengandung protein dengan pelepasan gas secara terus menerus membuat kandungan amonium dalam air meningkat. Amonium merupakan nutrisi bagi pertumbuhan alga, 
walaupun baik bagi pertumbuhan alga apabila kehadiran amonium yang berlebih dalam aliran air dapat menyebabkan eutrofikasi. Efek negatif dari eutrofikasi adalah jumlah oksigen terlarut di dalam air menjadi berkurang dan makhluk hidup di dalamnya akan mengalami kematian(2).

Konsentrasi amonium di perairan menurut PP No. 82 tahun 2001 kelas I, yaitu kadar amonium dalam air sungai < 0,5 ppm, agar air dapat digunakan untuk air minum dan ikan di dalam agar tetap hidup ${ }^{(3)}$. Kandungan amonium tidak boleh melebihi baku mutu agar air dapat digunakan dan makhluk hidup di dalamnya tetap hidup. Dalam pengolahan pengurangan amonium dalam air memiliki beberapa metode diantaranya adalah nitrifikasi-dentifikasi biologis, stripping udara dan adsorpsi (penukaran ion). Metode biologis memerlukan waktu yang cukup lama untuk mendapatkan hasil pengolahan yang

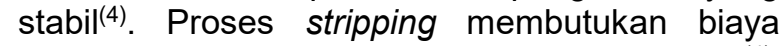
yang sangat tinggi dalam pengoprasiannya ${ }^{(4)}$. Metode adsorpsi merupakan cara yang sangat mudah dan biaya yang relatif murah untuk menghilangkan amonium dari dalam air. Zeolit alam memiliki kapasitas penukar kation, menukar ion dengan baik, dan kemampuan penyaringan molekuler yang tinggi( $\left.{ }^{2}\right)$ sehingga metode adsorpsi dengan zeolit alam cukup kompetitif karena berbiaya rendah dan jumlah di alam melimpah.

Provinsi Banten memiliki sumber zeolit alam yang cukup melimpah. Perkiraan cadangan zeolit alam Banten berdasarkan perhitungan kurang lebih $34.000 .000 \mathrm{~m}^{3}$ atau sekitar $68-81,6$ juta ton. Potensi zeolit terbesar di Provinsi Banten berada di Kabupaten Lebak lebih tepatnya di Kecamatan Bayah $^{(5)}$. Ketersediaan zeolit di daerah Bayah sangat melimpah dan belum dimanfaatkan dengan baik karena zeolit yang dihasilkan masih belum diketahui kualitasnya sehingga perlu untuk diteliti karakteristik dan kualitas zeolit. Selain itu, sebagian besar masyarakat di Bayah bahkan di Indonesia belum mengetahui manfaat dan cara pengaplikasian zeolit alam. Hal ini dapat dilihat dari aktivitas pertanian di Indonesia yang lebih mengandalkan pupuk kimia sintetik. Di berbagai negara asia seperti Thailand, Vietnam, Malaysia, dan Jepang, zeolit alam banyak digunakan sebagai pupuk pertanian.

Zeolit alam dapat ditemukan di daerah Bayah di berbagai tempat. Di setiap lokasi memiliki kondisi lingkungan yang berbeda-beda, sehingga pada setiap tempat zeolit alam memiliki karakteristik dan kualitas adsorpsi yang berbeda.

Kemampuan adsorpsi zeoit alam untuk adsorpsi amonium dapat dipelajari dengan menggunakan model isoterm Freundlich, Langmuir, dan Temkin sedangkan untuk mengetahui laju adsorpsi zeolit untuk adsorpsi amonium dapat dioptimasi dengan menggunakan model kinetika pseudo first order, pseudo second order, Elovich, dan intraparticle diffusion.

Penelitian mengenai penentuan karakteristik dan kemampuan adsorpsi amonium $\left(\mathrm{NH}_{4}{ }^{+}\right)$ dengan zeolit alam Bayah yang berasal dari lokasi yang berbeda masih jarang diteliti. Pada penelitian yang telah dilakukan di antaranya mengenai karakterisasi zeolit alam Bayah(6), modifikasi zeolit alam bayah menggunakan asam dan pengaplikasiannya dalam pengurangan amonium pada kolam ikan bandeng ${ }^{(7)}$, dan modifikasi zeolit alam Bayah menggunakan basa untuk aplikasi eliminasi di dalam kolam bandeng(8). Pengetahuan mengenai pengaruh lokasi tambang zeolit dapat memberikan kontribusi untuk pemahaman karakteristik zeolit alam Bayah.

\subsection{Tujuan Penelitian}

Penelitian ini bertujuan untuk menentukan zeolit alam yang memiliki daya adsorpsi terbesar dari 4 lokasi berbeda, melakukan karakterisasi zeolit alam Bayah, serta memodelkan persamaan kesetimbangan dan kinetika reaksi adsorpsi amonium.

\section{BAHAN DAN METODE}

\subsection{BAHAN}

Bahan yang digunakan penelitian ini adalah zeolit alam yang diambil dari empat lokasi berbeda dari Kecamatan Bayah, Kabupaten Lebak, Provinsi Banten, Indonesia, dengan ukuran -12+16 mesh, Amonium klorida $\mathrm{NH}_{4} \mathrm{Cl}$ (Sigma Aldrich), Aqua DM.

\subsection{METODE}

\subsubsection{Pengaruh Lokasi Zeolit Alam Terhadap Adsorpsi Amonium Oleh Zeolit Alam Bayah}

Adsorpsi dilakukan dengan sistem batch pada kondisi suhu ruang. Jumlah zeolit alam yang digunakan 10,5 , dan $1 \mathrm{~g}$. Sebanyak empat sampel dari lokasi berbeda yang ditambahkan dalam reaktor mengandung $50 \mathrm{~mL}$ larutan amonium dengan konsentrasi $100 \mathrm{ppm}$ kemudian didiamkan selama $3 \times 24$ jam dan diukur dengan kolorimeter.

Penyisihan amonium dihitung dengan menggunakan persamaan 1 sebagai berikut.

$\%$ penyisihan amonium $=\frac{C_{0}-C_{e}}{C_{0}} x 100 \% \ldots \ldots \ldots$ (1)

Dengan $C_{0}$ adalah konsentrasi amonium mula-mula $(\mathrm{mg} / \mathrm{L})$ dan $C_{e}$ adalah konsentrasi akhir dari amonium (mg/L). 


\subsubsection{Uji Karakteristik Zeolit dengan Analisis $X$-ray diffraction (XRD)}

Analisis X-ray diffraction (XRD) bertujuan untuk mengetahui tipe dan kristalinitas zeolit alam Bayah. Pertama adalah menyiapkan sampel zeolit dan mencuci dengan akuades dan diaduk selama 1 jam. Sampel dikeringkan pada suhu $105{ }^{\circ} \mathrm{C}$ menggunakan oven. Sampel zeolit yang telah kering dihancurkan dan disaring sampai ukuran -40+60 mesh, setelah itu analisis menggunakan $X$-ray diffraction (XRD).

\subsubsection{Uji Karakteristik Zeolit dengan Analisis Scanning Electron Microsope (SEM)- EDS (Energy Dispersive Spectrometer)}

Analisis Scanning Electron Microsope (SEM) dilakukan untuk mengetahui morfologi zeolit alam. Uji EDS dilakukan untuk mengetahui komposisi elemental dari zeolit alam.

\subsubsection{Uji Luas Permukaan Zeolit dengan Analisis Brunauer-Emmett-Teller (BET)}

Pada uji luas permukaan zeolit dengan menggunakan analisis adsorpsi desorpsi nitrogen. Sampel dikeringkan pada temperatur $300{ }^{\circ} \mathrm{C}$ kondisi vakum selama 6 jam. Adsorpsi gas nitrogen dilakukan pada temperature kriogenik $-196{ }^{\circ} \mathrm{C}$. Model Brunauer-EmmettTeller (BET) digunakan untuk menghitung luas permukaan sampel. Model BJH (Barrett, Joyner, and Halenda) digunakan untuk menghitung distribusi ukuran pori.

\subsubsection{Adsorpsi Amonium dengan Studi Kestimbangan}

Adsorpsi dilakukan dengan sistem batch pada kondisi suhu ruang, jumlah adsorben atau zeolit alam yang digunakan dengan variasi 0,$5 ; 1$; 1,$5 ; 2 ; 2,5 ; 3 ; 3,5$ dan $10 \mathrm{~g}$. yang ditambahkan dalam reaktor yang mengandung $50 \mathrm{ml}$ larutan amonium klorida dengan konsentrasi $100 \mathrm{ppm}$ (100 mg/L) kemudian didiamkan selama $3 \times 24$ jam. Setelah mencapai kesetimbangan sempel adsorben dipisahkan dengan kertas saring. Selanjutnya larutan amonium klorida diukur dengan menggunakan kolorimeter dan menghitung kandungan $\mathrm{NH}_{4}{ }^{+}$yang teradsorpsi. Pada studi kesetimbangan hasil percobaan akan dioptimasi dengan model isoterm Freundlich $\left(\mathrm{q}_{\mathrm{e}}=\right.$ $\left.\mathrm{K}_{\mathrm{f}} \mathrm{Ce}^{1 / \mathrm{n}}\right)$, Langmuir $\left(q_{e}=\frac{q_{\max } \mathrm{ke}}{1+\mathrm{kCe}}\right)$, dan Temkin $\left(q_{e}=B \operatorname{In}\left(K_{T} C_{e}\right)\right.$.

\subsubsection{Adsorpsi Amonium dengan Studi kinetika}

Adsorpsi dilakukan dengan sistem batch pada kondisi suhu ruang. Jumlah adsorben atau zeolit alam yang digunakan $10 \mathrm{~g}$ sebanyak satu sampel yang memiliki penyerapan terbesar ditambahkan dalam reaktor yang mengandung $50 \mathrm{ml}$ larutan amonium klorida dengan konsentrasi $100 \mathrm{mg} / \mathrm{L}$. Didiamkan selama 420 menit dengan diukur konsentrasi amonium setiap 60 menit sekali dengan menggunakan kolorimeter dan menghitung konsentrasi $\mathrm{NH}_{4}{ }^{+}$ yang teradsorpsi. Pada studi kinetika hasil percobaan dimodelkan dengan model pseudofirst order $\left(\frac{d q_{t}}{d t}=k_{1}\left(q_{e}-q_{t}\right)\right)$, pseudo-second $\operatorname{order}\left(\frac{d q_{t}}{d t}=k_{1}\left(q_{e}-q_{t}\right)^{2}\right)$, Elovich $\left(q_{t}=\frac{1}{\beta} \ln (1+\right.$ $\alpha \beta t))$, dan intrapartikel difusi $\left(q_{t}=k_{i} t^{1 / 2}+C\right)$.

\section{HASIL DAN PEMBAHASAN}

\subsection{Pengaruh Lokasi Zeolit Alam Bayah}

Dalam penelitian ini, hal pertama yang dilakukan yaitu zeolit alam yang memiliki adsorpsi amonium terbesar dari empat lokasi di Bayah. Ukuran zeolit diperkecil menjadi $-12+16$ mesh bertujuan untuk memperluas permukaan zeolit alam sehingga dapat meningkatkan keaktifan zeolit alam. Studi adsorpsi amonium menggunakan zeolit alam Bayah dari empat lokasi yang berbeda. Hasil adsorpsi amonium disajikan pada Gambar 1.

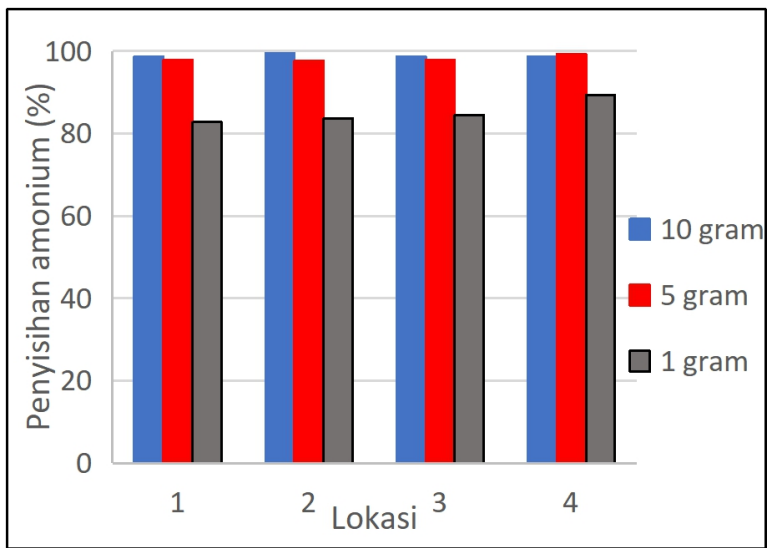

Gambar 1. Diagram studi adsorpsi amonium oleh zeolit alam bayah dari empat lokasi

Zeolit alam 1, 2, 3, dan 4 merupakan zeolit alam yang berlokasi di Desa Pasirgombong kecamatan Bayah Provinsi Banten. Namun, zeolit alam 1, 2, 3, dan 4 memiliki titik koordinat yang berbeda masing-masing titik koordinatnya yaitu $\quad(-6.880998,106.298468)$, 6.879858,106.297991), (-6.878265,106.297338), dan $(-6.877756,106.297666)$. Keempat lokasi zeolit alam bayah diambil berdasarkan tambang zeolit yang telah di manfaatkan oleh masyarakat Bayah sehingga penting untuk mengetahui kualitas masing-masing zeolit alam. Zeolit alam tersebut memiliki adsorpsi yang berbeda dari setiap variasi massa 10 gram, 5 gram, dan 1 gram. Pada variasi 10 gram zeolit alam Bayah lokasi $1,2,3$, dan 4 , dapat mengurangi kadar 
amonium sebesar 98,7\% ; 99,5\% ; 98,65 \% dan $98,7 \%$. Pada variasi 5 gram zeolit alam Bayah lokasi 1, 2, 3, dan 4, dapat mengurangi kadar amonium sebesar 97,85\%; 97,7\%; 97,9\% dan $99,25 \%$. Pada variasi 1 gram zeolit alam Bayah lokasi 1, 2, 3, dan 4, dapat mengurangi kadar amonium sebesar $82,75 \%$; 83,75\% ; 84,55 \% dan $89,4 \%$. Studi adsorpsi amonium terbesar diperoleh pada zeolit alam Bayah lokasi 4 (titik koordinat $-6.877756,106.297666)$. Pada variasi zeolit alam 5 gram dan 1 gram ditemukan bahwa zeolit alam Bayah lokasi 4 memiliki penyisihan amonium terbesar yaitu sebesar 99,25\% dan $89,4 \%$. Pada variasi zeolit alam 10 gram diperoleh penyisihan amonium terbesar pada lokasi 2, namun perbedaannya tidak signifikan. Hal ini dapat dikarenakan jumlah zeolit alam yang digunakan terlalu banyak dibandingkan dengan konsentrasi amonium sehingga konsentrasi amonium dapat teradsorp habis oleh zeolit alam Bayah lokasi 1, 2, 3, dan 4.

\subsection{Karakterisasi Zeolit Alam Bayah}

\section{a) Analisis XRD}

Hasil XRD dengan menggunakan sinar $X$ dapat dilihat pada Gambar 2. International Zeolite Association (IZA) menyatakan bahwa tipe Zeolit memiliki 234 jenis yang terdiri dari 67 tipe zeolit alam dan 167 zeolit sintetis. Tipe zeolit alam yang sering ditemukan biasanya adalah mordenit, kabasit, klinoptilolit, heulandite, dan quartz ${ }^{(9)}$. Pada penelitian ini dilakukan karakterisasi zeolit alam Bayah dari empat lokasi berbeda yang akan ditentukan tipe fasa kristal pada zeolit alam Bayah. Setelah dilakukan analisis bahwa zeolit alam Bayah memiliki kandungan fasa mordenit, klinoptilolit, heulandit, dan quartz. Hal ini dapat dilihat dari grafik analisis X-ray Diffraction (XRD) pada Gambar 2.

Gambar 2 menunjukkan perbandingan antara zeolit alam Bayah dari lokasi 1, 2, 3, dan 4. Untuk melakukan analisis fasa mordenit, klinoptilolit, heulandit, dan quartz dilakukan perbandingan dengan pola difraksi zeolit standar mordenit, klinoptilolit, heulandite, dan quartz. Fase mordenit dalam grafik dilambangkan dengan segitiga biru fasa klinoptilolit dilambangkan dengan bulat merah, fasa heulandit dilambangkan dengan kotak hijau, dan quart dilambangkan dengan bintang. Pola difraksi zeolit alam Bayah dibandingkan dengan grafik standar fase mordenit, klinoptilolit, heulandit, dan quartz. Pada saat nilai $2 \theta$ memiliki titik puncak di titik yang sama baik dari zeolit alam dan zeolit standar maka zeolit alam mengandung fase tersebut. Dari keempat sampel zeolit alam memiliki intensitas di titik $2 \theta$ yang sama meskipun memiliki nilai intensitas yang berbeda dengan standar. Berdasarkan hasil analisis, zeolit alam Bayah didominasi oleh fase mordenit dan klinoptilolit. Zeolit alam yang telah ditambang secara intensif di Indonesia diantaranya untuk wilayah jawa barat yaitu Bayah, Cikalong, dan Tasikmalaya sebagian besar dikenal sebagai jenis zeolit klinoptilolit dan mordenit ${ }^{(10)}$. Untuk penelitian ini diperoleh zeolit alam Bayah dari empat lokasi yang berbeda mengandung jenis zeolit klinoptilolit, mordenit, heulandit, dan quartz.
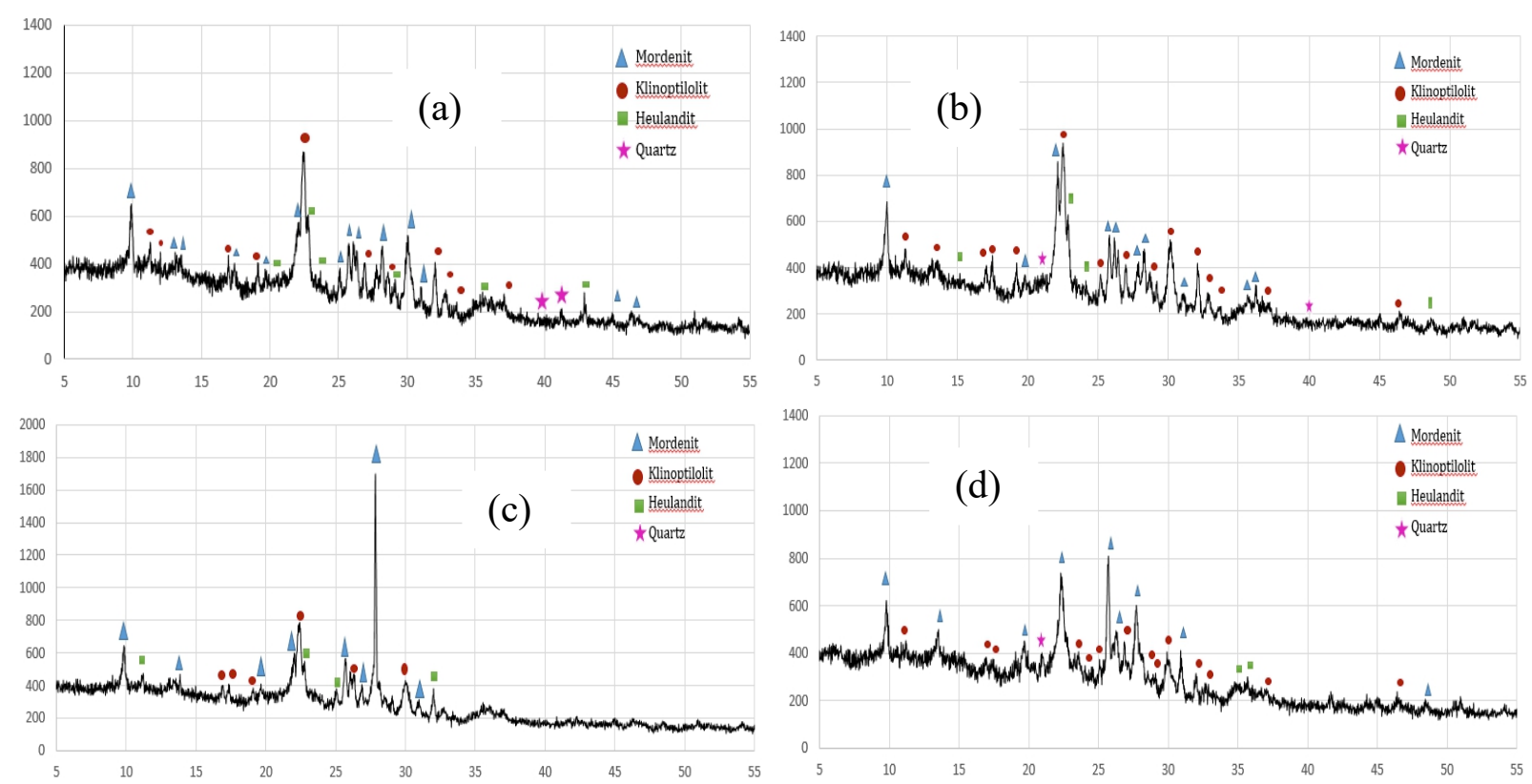

Gambar 2. Hasil analisis X-ray diffraction (XRD) zeolit alam Bayah, (a) zeolit alam lokasi 1, (b) zeolit alam lokasi 2, (c) zeolit alam lokasi 3, dan (d) zeolit alam lokasi 4. Sumbu X merupakan nilai $2 \theta$ dan sumbu $Y$ merupakan intensitas. 


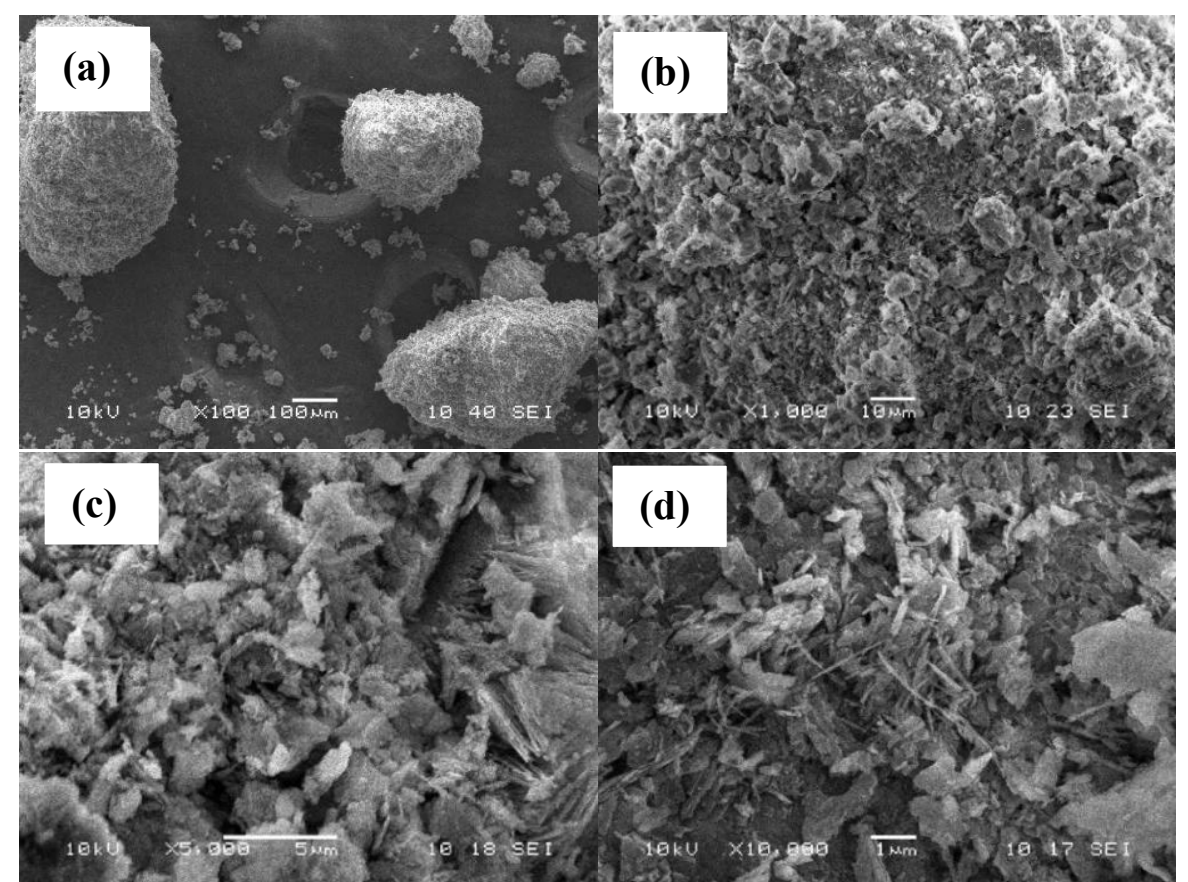

Gambar 3. Hasil analisis Scanning Elektron Microscopy (SEM), (a) 100 kali pembesaran, (b) 1000 kali pembesaran, (c) 5000 kali pembesaran, dan (d) 10000 kali pembesaran.

\section{b) Analisis SEM-EDS}

Untuk mengetahui morfologi permukaan zeolit alam maka dilakukan pengujian dengan menggunakan SEM (Scanning Electron Microscopy). Analisis dilakukan pada sampel zeolit alam lokasi 4 untuk mengetahui morfologi zeolit alam yang memiliki jenis zeolit mordenit, klinoptilolit, heulandit, dan quartz yang sebelumnya telah dilakukan pengujian dengan analisis XRD.

Pada Gambar 3 menunjukkan bahwa perbesaran 100 kali terlihat partikel-partikel yang memiliki bentuk berbeda-beda, partikel tersebut dilakukan pembesaran 1000 kali terlihat partikel tersebut tersusun dari partikel-partikel yang lebih kecil. Pada perbesaran 5000 kali dan 10.000 kali terlihat tekstur permukaannya memiliki serat yang runcing seperti jarum dan banyak serat yang tidak berbentuk. Bentuk serat seperti jarum merupakan ciri dari zeolit mordenit(11). Serat yang tidak berbentuk dapat diindikasikan sebagai jenis zeolit lain atau fasa kristalin lain. Berdasarkan Gambar 3, ukuran rongga atau pori tidak terlihat, walaupun sudah diperbesar sampai perbesaran 10000 kali. Pada Tabel 1. Analisis EDS dilakukan untuk mengetahui kandungan unsurunsur yang terdapat pada zeolit alam. Berdasarkan hasil analisis EDS dapat diketahui bahwa sebagian besar senyawa penyusun zeolit alam Bayah dalam bentuk oksida seperti pada senyawa-senyawa $\mathrm{MgO}, \mathrm{Al}_{2} \mathrm{O}_{3}, \mathrm{SiO}_{2}, \mathrm{~K}_{2} \mathrm{O}, \mathrm{CaO}$, dan $\mathrm{FeO}$. Kandungan senyawa penyusun zeolit alam Tasikmalaya terdiri dari $\mathrm{MgO}, \mathrm{Al}_{2} \mathrm{O}_{3}, \mathrm{SiO}_{2}$, $\mathrm{K}_{2} \mathrm{O}, \mathrm{CaO}, \mathrm{Na}_{2} \mathrm{O}$, dan $\mathrm{Fe}_{2} \mathrm{O}_{3}{ }^{(10)}$. Zeolit alam Malang terdiri dari senyawa $\mathrm{MgO}, \mathrm{Al}_{2} \mathrm{O}_{3}, \mathrm{SiO}_{2}$,
$\mathrm{K}_{2} \mathrm{O}, \mathrm{Na}_{2} \mathrm{O}$, dan $\mathrm{Fe}_{2} \mathrm{O}_{3}{ }^{(12)}$. Zeolit alam Bayah, Tasikmalaya, dan Malang memiliki kandungan yang berbeda, hal ini berarti kandungan yang terdapat pada zeolit alam dipengaruhi oleh lokasi zeolit tersebut.

Tabel 1. Hasil analisis EDS (Energi Dispersive Spectrometer)

\begin{tabular}{lcc}
\hline \multicolumn{1}{c}{ Unsur } & Massa \% & Atom \% \\
\hline $\mathbf{O}$ & 47,36 & \\
$\mathbf{M g}$ & 0,61 & 1,65 \\
$\mathbf{A l}$ & 8,13 & 9,91 \\
$\mathbf{S i}$ & 32 & 74,96 \\
$\mathbf{K}$ & 4,24 & 3,57 \\
$\mathbf{C a}$ & 1,89 & 3,11 \\
$\mathbf{F e}$ & 5,77 & 6,8 \\
\hline Total & 100 & 100 \\
\hline
\end{tabular}

Pada analisis EDS zeolit alam Bayah memiliki kandungan unsur $\mathrm{O}$ yang paling besar dari unsur lain yaitu $47,36 \%$. Kandungan terbesar lainnya diikuti silika dan alumina yaitu $32 \%$ dan $8,13 \%$. Hal ini sesuai dengan komposisi senyawa zeolit yang disusun atas senyawa silika dan alumina. Senyawa-senyawa yang terdapat pada zeolit alam Bayah yaitu $\mathrm{MgO}$, $\mathrm{Al}_{2} \mathrm{O}_{3}, \mathrm{SiO}_{2}, \mathrm{~K}_{2} \mathrm{O}, \mathrm{CaO}$, dan $\mathrm{FeO}$. Senyawa tersebut merupakan senyawa penyusun zeolit yang dimana unsur $\mathrm{K}$, $\mathrm{Fe}$, dan $\mathrm{Ca}$ merupakan kation yang terdapat di alam sehingga dapat berikatan dengan penyusun utama zeolit yaitu alumina dan silika. 


\section{c) Adsorpsi-Desorpsi Nitrogen}

Analisis Adsorpsi-Desorpsi Nitrogen digunakan untuk menentukan ukuran pori, volume pori dan luas permukaan berturut-turut melalui metode Isoterm Langmuir, BJH, dan BET. Proses analisis material berpori dapat diketahui melalui metode grafik isoterm langmuir berdasarkan nilai perbandingan $\mathrm{P} / \mathrm{Po}(\mathrm{mmHg})$ terhadap volume $\mathrm{N}_{2}$ per gram sampel $(\mathrm{ml} / \mathrm{g})$ dan grafik metode BJH (Barret, Joiner, Halenda). Sifat khas material mesopori dapat dilihat dengan loop historisis atau percabangan ${ }^{(13)}$. Pada grafik isoterm nitrogen yang ditunjukkan pada Gambar 4.(a) menggambarkan grafik yang merupakan sifat khas material mesopori dimana terdapat loop histerisis pada zeolit alam Bayah pada tekanan relatif (P/Po) sekitar 0,5-1 yang menunjukkan terjadinya pengisian mesopori. Hal ini mengindikasikan zeolit alam Bayah lokasi empat memiliki mesopori. Indikasi tersebut diperkuat dengan terjadinya loop histerisis atau percabangan yaitu ketika tekanan diturunkan untuk desorpsi gas nitrogen dimana jumlah gas yang terdesorpsi tidak sama dengan jumlah gas yang teradsorpsi di awal. Pada tekanan relatif 0,45-1 yang sama, jumlah gas yang tertinggal di permukaan material ketika desorpsi masih lebih banyak dibandingkan ketika adsorpsi. Dengan kata lain, jumlah gas yang terdesorpsi masih lebih banyak dibandingkan ketika adsorpsi. Loop histerisis disebabkan oleh fenomena kondensasi di dalam mesopori zeolit alam. Isoterm adsorpsidesorpsi nitrogen menunjukkan adanya loop histerisis. Loop histerisis dapat dilihat saat desorpsi pada tekanan relatif (P/Po) 0,45-1 pada zeolit alam Bayah.
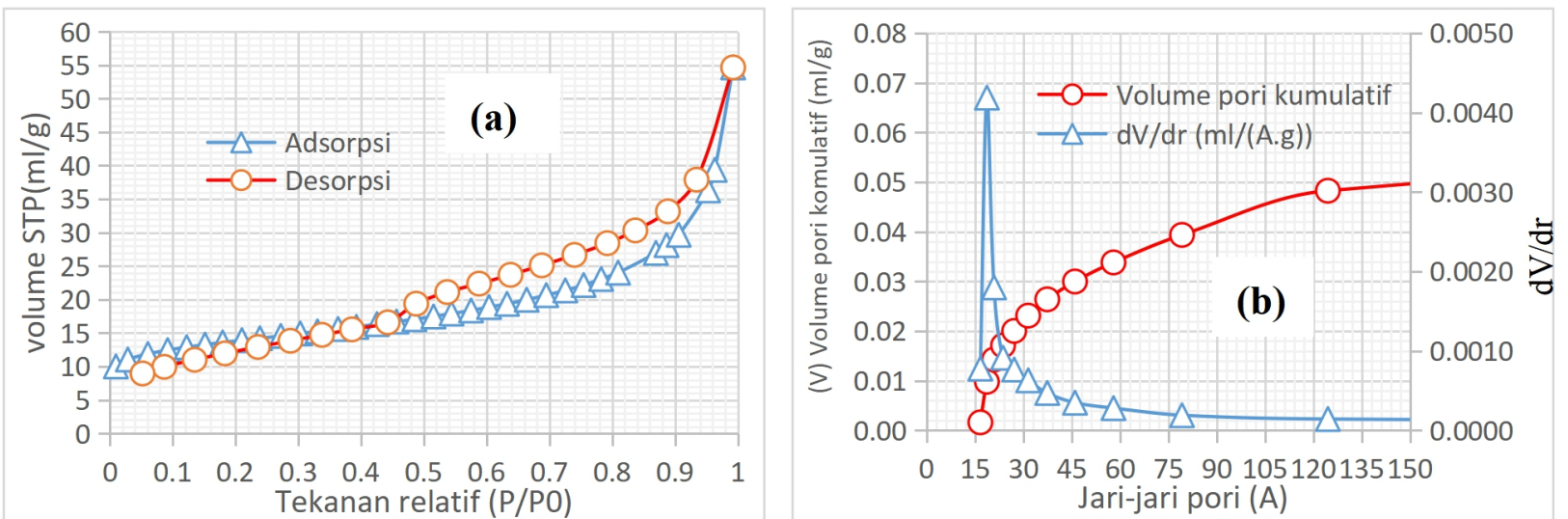

Gambar 4. Grafik analisis BET (Brunaeur Emmet Teller), (a) Isoterm adsorpsi-desorpsi nitrogen, (b) Metode BJH desorpsi

Tabel 2. Sifat tekstural zeolit alam Bayah lokasi 4

\begin{tabular}{lcc}
\hline \multicolumn{1}{c}{ Sifat } & Kuantitas & Satuan \\
\hline Luas Permukaan & 46 & $\mathrm{~m}^{2} / \mathrm{g}$ \\
Luas Mikropori & 20 & $\mathrm{~m}^{2} / \mathrm{g}$ \\
Luas Mesopori & 26 & $\mathrm{~m}^{2} / \mathrm{g}$ \\
Volume Mikropori & 0,01 & $\mathrm{ml} / \mathrm{g}$ \\
Volume Mesopori & 0,07 & $\mathrm{ml} / \mathrm{g}$ \\
Volume Total & 0,08 & $\mathrm{ml} / \mathrm{g}$ \\
\hline
\end{tabular}

Ukuran padatan bermesopori juga dapat dilihat dari data grafik distribusi ukuran pori dengan menggunakan metode BJH (Barret, Joiner, Halenda). Material mikropori merupakan material yang memiliki diameter pori kurang dari $2 \mathrm{~nm}$, sedangkan material mesopori merupakan material yang memiliki diameter pori 2-50 $\mathrm{nm}^{(11)}$. Metode BJH dapat menganalisis jari-jari mikropori dan mesopori, sehingga hal ini dapat mengetahui total volume mesopori pada zeolit alam Bayah. Pada gambar 4.(b) bahwa jari-jari pori semakin besar maka volume pori komulatif akan semakin besar dan volume mesopori yang paling besar terdapat pada jari-jari mesopori 20 $\AA$ terlihat pada perbandingan volume mesopori dengan jari-jari pori. Berdasarkan analisis BET didapatkan bahwa luas pori dan volume pori disajikan di dalam Tabel 2.

Analisis BET (Brunaeur-Emmet-Teller) dilakukan untuk mengetahui luas permukaan spesifik, volume mesopori, dan jari-jari pori dari zeolit. Pada penelitian ini diperoleh luas permukaan zeolit alam Bayah sebesar $46 \mathrm{~m}^{2} / \mathrm{g}$. Pada penelitian yang telah dilakukan sebelumnya zeolit alam dari beberapa daerah seperti Lampung, Tasikmalaya, dan Gunungkidul yang telah dilakukan analisis BET memiliki luas permukan yang berbeda-beda. Zeolit alam Gunungkidul tanpa modifikasi memiliki luas permukaan sebesar $32 \mathrm{~m}^{2} / \mathrm{g}^{(14)}$. Luas permukaan zeolit alam Tasikmalaya tanpa modifikasi sebesar $4 \mathrm{~m}^{2} / \mathrm{g}^{(15)}$. Zeolit alam lampung yang tidak dimodifikasi memiliki luas permukaan sebesar $2 \mathrm{~m}^{2} / \mathrm{g}^{(16)}$. Dibandingkan dengan ketiga zeolit alam tersebut, zeolit alam Bayah dari lokasi empat memiliki luas permukaan yang paling besar. Semakin besar luas permukaan 
zeolit alam maka semakin banyak kation yang dapat dipertukarkan. Hal ini berarti zeolit alam Bayah memiliki potensi kemampuan adsorpsi yang lebih besar.

\subsection{Studi Kesetimbangan Adsorpsi Amonium}

Percobaan isoterm adsorpsi untuk zeolit alam Bayah lokasi 4 dilakukan dengan variasi massa zeolit alam Bayah yaitu $0,5 \mathrm{~g} ; 1 \mathrm{~g} ; 1,5 \mathrm{~g}$; $2 \mathrm{~g} ; 2,5 \mathrm{~g} ; 3 \mathrm{~g} ; 3,5 \mathrm{~g} ; 10 \mathrm{~g}$, dan amonium $\left(\mathrm{NH}_{4}{ }^{+}\right)$sebanyak $50 \mathrm{~mL}$ dengan konsentrasi 100 ppm. Data percobaan adsorpsi dimodelkan dengan isoterm Langmuir, isoterm Freundlich, dan isoterm Temkin. Hasil isoterm adsorpsi dari ketiga metode ditunjukkan pada Tabel 3. Model isoterm adsorpsi yang sesuai dengan data hasil penelitian yang dioptimasi dengan analisis linierisasi dan non-linerisasi yaitu dengan melihat data nilai Sum of Square Error (SSE) yang paling kecil. Berdasarkan nilai SSE yang dioptimasi dengan non-linierisasi dari ketiga model isoterm memiliki nilai rata-rata lebih kecil dibandingkan dengan metode optimasi linierisasi. Sehingga metode optimasi non-linierisasi lebih baik dibandingkan dengan metode optimasi linearisasi.

Tabel 3. Rekapitulasi perhitungan isoterm

Zeolit Alam Bayah Lokasi 4

\begin{tabular}{|c|c|c|c|c|c|c|}
\hline \multirow[t]{2}{*}{ Metode Optimasi } & \multicolumn{2}{|c|}{ Langmuir } & \multicolumn{2}{|c|}{ Freundlich } & \multicolumn{2}{|r|}{ Temkin } \\
\hline & $q \max$ & 10,384 & $\mathrm{k}$ & 1,2187 & $\mathrm{~K}$ & 0,65502 \\
\hline \multirow{5}{*}{ Linierisasi } & $\mathrm{k}$ & 0,1164 & $\mathrm{n}$ & 2,0597 & beta & 2,4739 \\
\hline & SSE & 7,5647 & SSE & 3,333 & SSE & 0,90627 \\
\hline & $q=\frac{}{1}$ & $\frac{2087 \mathrm{Ce}}{0,1164 \mathrm{Ce}}$ & \multicolumn{2}{|c|}{$q=1,2187 C e^{\frac{1}{2,0597}}$} & \multicolumn{2}{|c|}{$q=2,4739 \operatorname{In}(0,65502)$} \\
\hline & $q \max$ & 56,8753 & $\mathrm{k}$ & 0,89 & $\mathrm{k}$ & 0,6542 \\
\hline & k & 0,0058 & $\mathrm{n}$ & 1,515 & beta & 2,4768 \\
\hline \multirow{2}{*}{ Non-Linierisasi } & SSE & 5,0828 & SSE & 0,16767589 & SSE & 0,90632 \\
\hline & $q=\frac{1}{1}$ & $\frac{3299 \mathrm{Ce}}{0,0058 \mathrm{Ce}}$ & \multicolumn{2}{|c|}{$q=0,89 C e^{\frac{1}{1,515}}$} & \multicolumn{2}{|c|}{$q=2,4768 \operatorname{In}(0,6542)$} \\
\hline
\end{tabular}

Dari model isoterm Langmuir, isoterm Freundlich, dan isoterm Temkin yang paling cocok dengan hasil percobaan yaitu model isoterm freundlich karena memiliki nilai SSE yang paling kecil. Isoterm Freundlich merupakan model isoterm adsorpsi yang menggunakan penurunan persamaan empiris yang dicocokkan dengan hasil percobaan. Isotrem Langmuir merupakan adsorpsi yang memiliki satu lapisan tunggal (monolayer) dan homogen ${ }^{(17)}$. Isoterm Temkin merupakan mekanisme adsorpsi yang terjadi secara kimia(17). Berikut ini merupakan grafik pemodelan isoterm Freundlich, isoterm Langmuir, dan isoterm Temkin.

Pada model isoterm Freundlinch memiliki nilai $\mathrm{K}$ dan $\mathrm{n}$ sebesar 0,89 dan 1,5. Nilai $\mathrm{K}_{\mathrm{F}}$ dan $\mathrm{n}$ merupakan parameter yang menunjukkan kapasitas adsorpsi suatu adsorben ${ }^{(18)}$. Jika parameter Freundlich $\left(\mathrm{K}_{\mathrm{F}}\right)$ semakin besar maka daya adsorpsi dari adsorben yang diuji akan semakin baik. Model isoterm Freundlich selain memiliki model yang cocok dengan percobaan, model ini juga memiliki daya adsorpsi paling baik.

Pada Gambar 5 garis hitam menunjukkan hasil pemodelan isoterm adsorpsi, dan lingkaran merah merupakan hasil percobaan adsorpsi amonium menggunakan zeolit alam Bayah lokasi empat. Dari ketiga grafik pada Gambar 5 menunjukkan bahwa model isoterm Freundlich sesuai dengan hasil percobaan. Model isoterm Langmuir menunjukkan hasil yang kurang sesuai dengan hasil percobaan, hal ini berarti adsorpsi amonium menggunakan zeolit alam Bayah tidak termasuk ke dalam adsorpsi yang memiliki satu lapisan tunggal (monolayer). Pada model isoterm Temkin menunjukkan bahwa model isoterm hampir mendekati dengan hasil percobaan. Isoterm Temkin menggambarkan perilaku sistem adsorpsi pada permukaan yang heterogen. Hal ini berarti bahwa adsorpsi amonium oleh zeolit alam Bayah memiliki permukaan yang heterogen.

Pada penelitian ini mengindikasikan kemungkinan adsorpsi amonium dengan zeolit alam Bayah berlangsung pada lapisan yang lebih dari satu layer atau multilayer. Adsorpsi yang lebih dari satu layer memiliki ikatan molekul yang tidak kuat pada permukaan. Adsorpsi multilayer sering terjadi pada proses reversibel yang cepat, sehingga bersifat mudah diganti dengan molekul lain(19). 


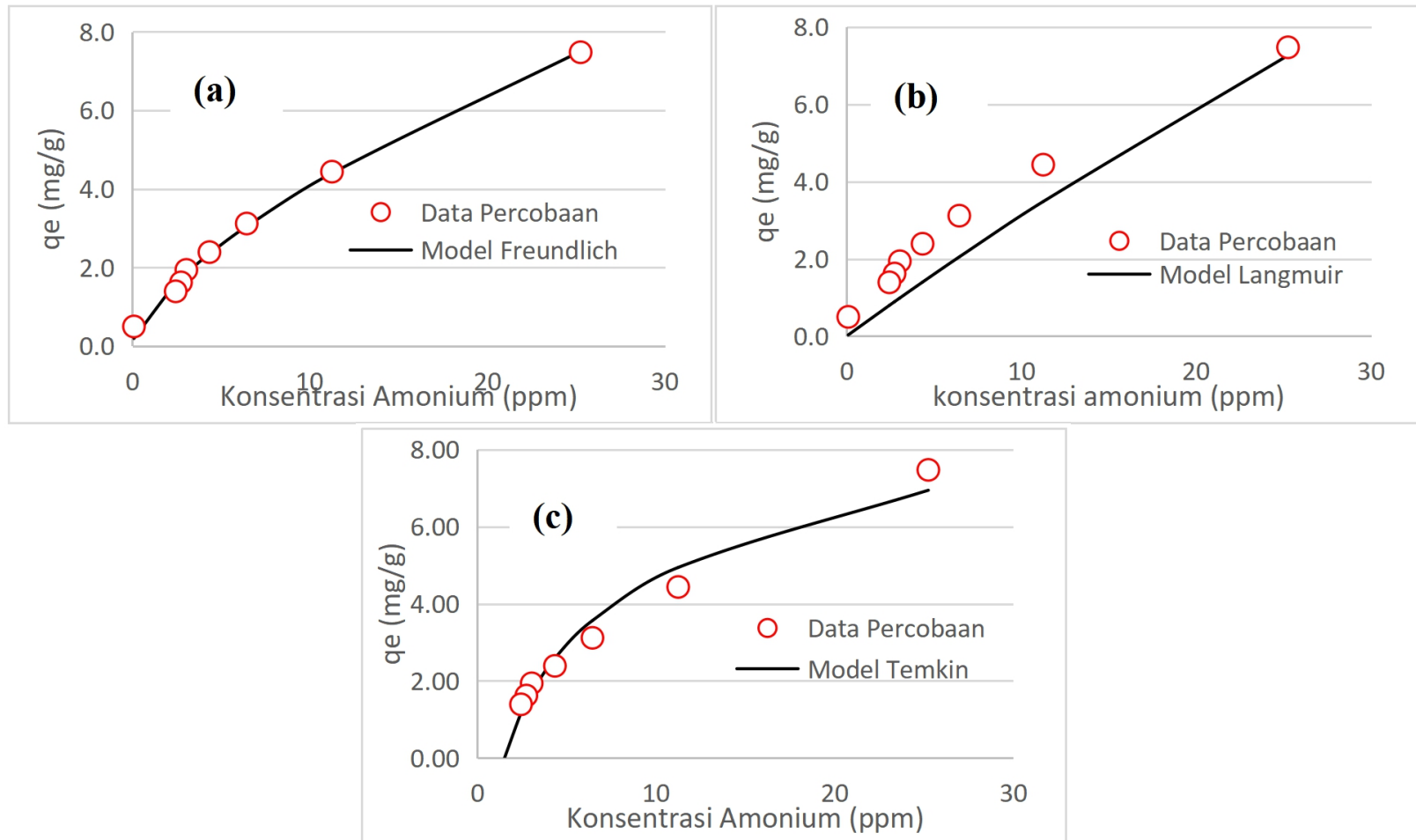

Gambar 5. Grafik pemodelan isoterm adsorpsi, (a) Isoterm Freundlich, (b) Isoterm Langmuir, (c) Isoterm Temkin

Tabel 4. Rekapitulasi perhitungan kinetika adsorpsi

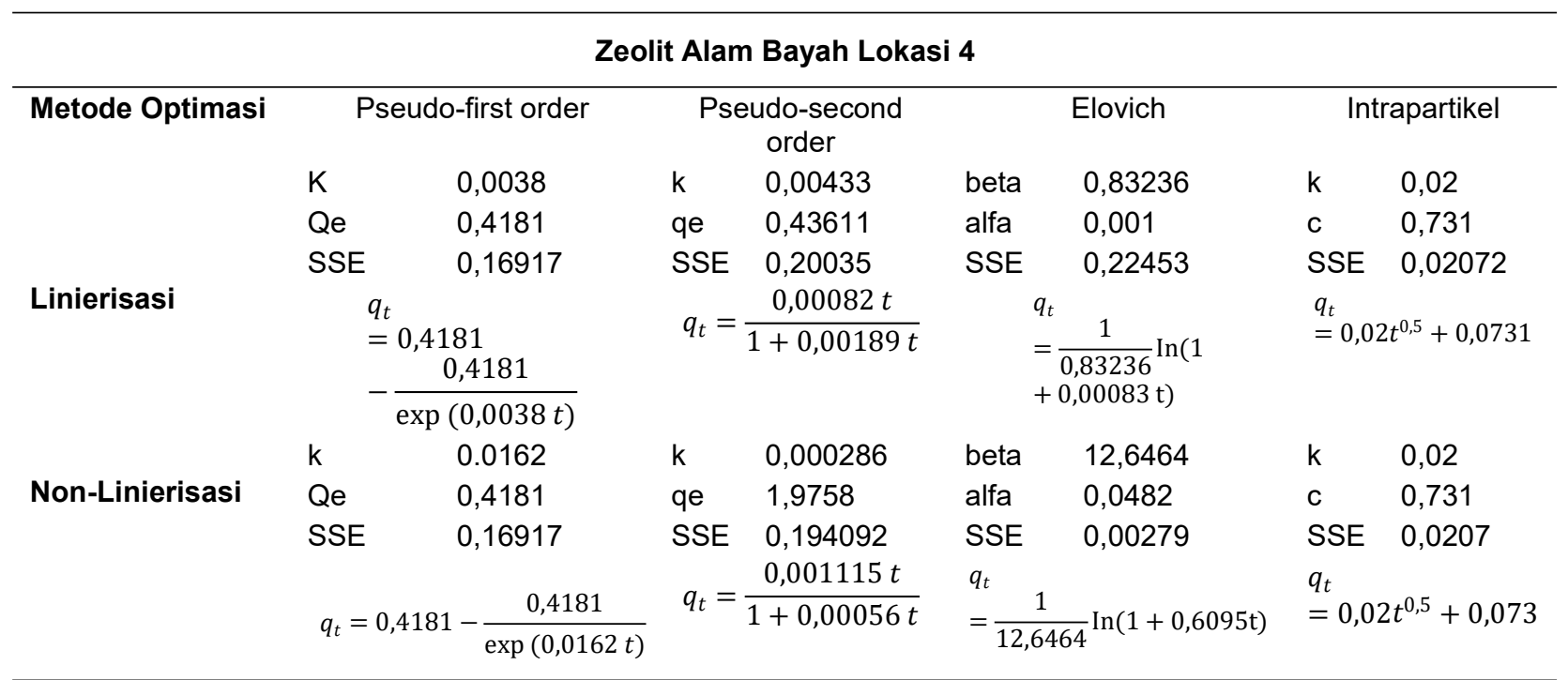

\subsection{Studi Kinetika Adsorpsi Amonium}

Model kinetika yang digunakan adalah pseudo-first order, pseudo-second order, Elovich, dan difusi intrapartikel. Model kinetika ini adalah yang umum digunakan untuk menggambarkan fenomena adsorpsi. Nilai SSE merupakan nilai yang menunjukkan eror dari model kinetika dengan hasil percobaan, semakin kecil nilainya maka semakin baik hasilnya. Model kinetika adsorpsi dioptimasi dengan analisis linierisasi dan non-linerisasi. Untuk menentukan model yang sesuai dengan hasil percobaan dapat ditentukan dari nilai Sum of Square Error (SSE) yang paling kecil. Berdasarkan hasil percobaan yang telah dioptimasi bahwa non-linierisasi memiliki nilai SSE rata-rata lebih kecil. Sehingga metode optimasi non-linierisasi lebih baik dibandingkan dengan metode optimasi linierisasi.

Pada percobaan ini diperoleh grafik perbandingan antara hasil percobaan kinetika adsorpsi amonium oleh zeolit alam Bayah dengan model kinetika adsorpsi. Berikut ini merupakan grafik pemodelan pseudo-first order, pseudo-second order, Elovich, dan intrapartikel difusi. 
Pada Gambar 6 garis hitam menunjukkan hasil pemodelan kinetika adsorpsi, dan lingkaran merah merupakan hasil percobaan adsorpsi amonium menggunakan zeolit alam Bayah lokasi empat. Dari keempat grafik pada Gambar 6 menunjukkan bahwa model kinetika pseudo-first order sesuai dengan hasil percobaan dan nilai SSE sebesar 0,000154.

Dari hasil percobaan diperoleh bahwa jumlah amonium yang teradsorpsi oleh zeolit alam Bayah mengalami peningkatan setiap pertambahan waktu. Namun, peningkatan amonium yang teradsorpsi tersebut semakin lama waktu, mengalami peningkatan yang tidak signifikan atau sangat kecil. Hal ini disebabkan karena banyaknya amonium yang teradsorpsi oleh zeolit alam pada setiap waktu akan betambah dan amonium akan menumpuk di permukaan zeolit sehingga mencapai kesetimbangan.

Pada model kinetika adsorpsi pseudo-first order dan pseudo-second order bahwa model kinetika yang paling cocok dengan dengan hasil percobaan adalah model kinetika adsorpsi pseudo-first order. Model kinetika ini biasa digunakan untuk laju adsopsi yang tidak begitu besar, sedangkan model kinetika pseudo-second order digunakan untuk menghitung laju adsorpsi yang sangat besar. Hal ini mengindikasikan bahwa zeolit alam Bayah memiliki laju adsorpsi amonium yang tidak terlalu besar.

Pada model kinetika adsorpsi Elovich memiliki model kinetika adsorpsi yang hampir cocok dengan hasil percobaan dengan nilai SSE sebesar 0,00279. Model kinetika Elovich dikembangkan untuk laju adsorpsi berdasarkan kapasitas jerapan pada permukaan yang heterogen ${ }^{(17)}$. Model kinetika adsorpsi Elovich memiliki model yang cukup baik bila dibandingkan dengan model kinetika intrapartikel difusi sehingga dapat dikatakan bahwa adsorpsi amonium oleh zeolit alam Bayah selain cocok dengan model kinetik adsorpsi pseudo-first order juga cocok dengan model kinetika adsorpsi Elovich. Hal ini merupakan indikasi bahwa amonium yang diadsorpsi oleh zeolit alam Bayah merupakan adsorpsi yang permukaan adsorbennya bersifat heterogen.
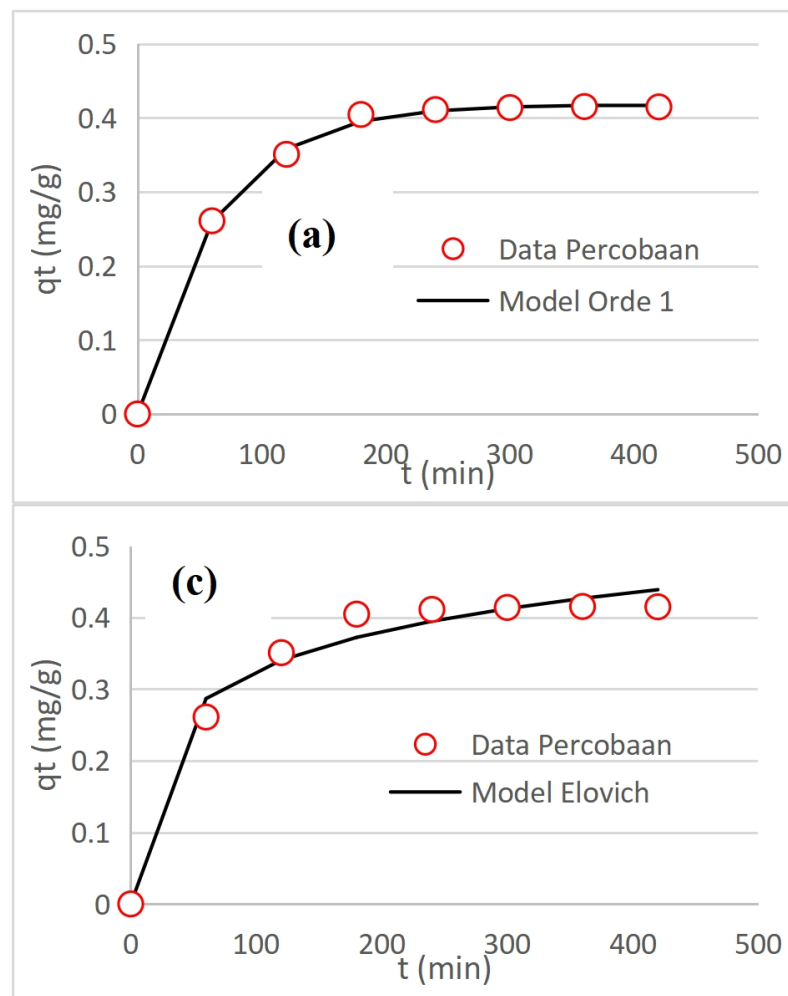
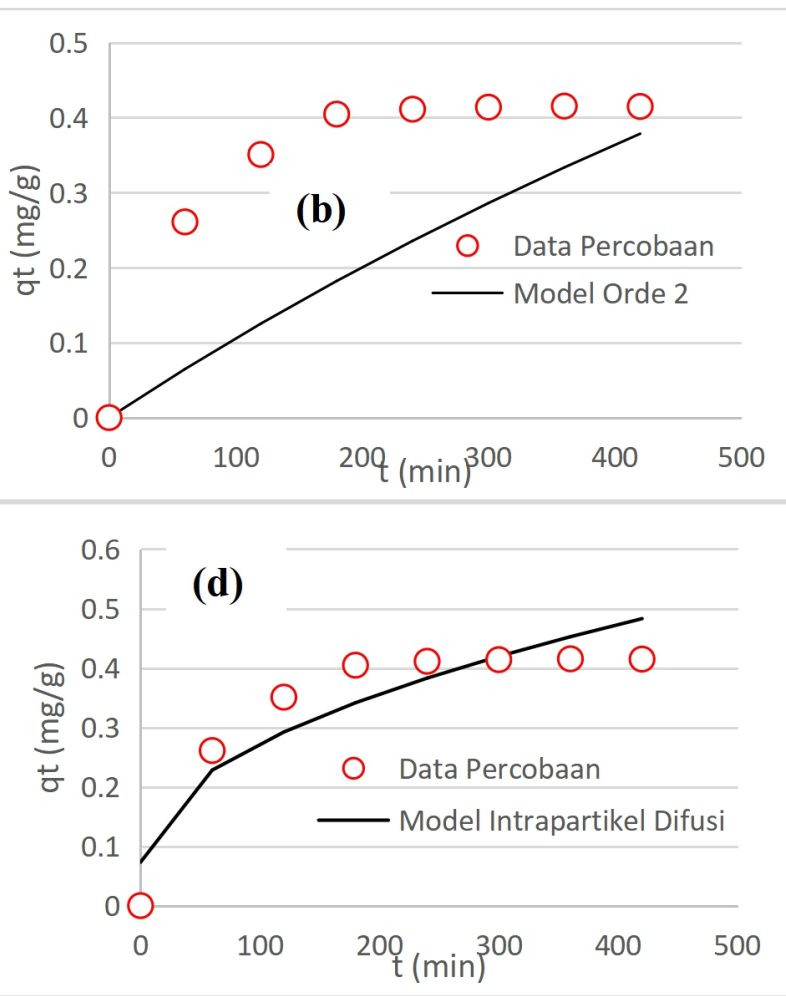

Gambar 6. Gafik pemodelan kinetika adsorpsi Elovich, (d) intrapartikel difusi

(a) pseudo-first order, (b) pseudo-second order, (c)

\subsection{Potensi Pemanfaatan Zeolit Bayah}

Berdasarkan karakterisasi yang telah dilakukan, zeolit alam Bayah memiliki potensi pemanfaatan di bidang pengolahan limbah dan air, pertanian, dan peternakan. Air limbah dan air baku yang memiliki kandungan amonium di atas

ambang batas dapat diolah terlebih dahulu dengan menggunakan zeolit alam Bayah. Unit operasi adsorpsi dapat digunakan untuk aplikasi zeolit Bayah sebagai adsorben amonium. Kolom adsorpsi yang dipasang umumnya berjumlah 2 buah, satu buah untuk operasi adsorpsi dan satu buah untuk operasi desorpsi atau lebih dikenal 
dengan istilah stripping. Pola operasi dilakukan secara bergantian, pada saat kolom satu mengadsorpsi amonium, kolom lainnya melucuti zeolit dari amonium. Pelucutan amonium bisa dilakukan dengan menggunakan air garam $\mathrm{NaCl}$. Selain untuk adsorben amonium, zeolit Bayah juga dapat digunakan untuk adsorpsi $\mathrm{Hg}$ yang mencemari tanah dan perairan di Bayah akibat penambangan emas tradisional. Zeolit alam dilaporkan memiliki kemampuan yang efektif sebagai adsorben merkuri dengan menggunakan metode subsurface flow constructed wetland $(\mathrm{SSF}-\mathrm{CW})^{(20)}$.

Zeolit alam Bayah berpotensi untuk dimanfaatkan dalam bidang pertanian dan peternakan. Daerah selatan Banten merupakan daerah pertanian. Oleh sebab itu, potensi zeolit perlu diangkat untuk dimanfaatkan dalam bidang pertanian. Zeolit alam berguna untuk memperbaiki struktur tanah dan sebagai bahan baku pembuatan pupuk lepas lambat. Selain itu, ransum ternak ruminansia yang dicampur dengan zeolit terbukti dapat meningkatkan bobot ternak. Dengan ketersedian zeolit alam Bayah yang melimpah, maka pemanfaatan zeolit untuk berbagai aplikasi dapat meningkatkan nilai ekonomi zeolit alam Bayah.

\section{KESIMPULAN}

Berdasarkan penelitian yang telah dilakukan dapat disimpulkan sebagai berikut:

a. Berdasarkan metode isoterm adsorpsi diperoleh zeolit alam Bayah yang memiliki adsorpsi amonium terbesar pada lokasi $4 \mathrm{di}$ titik koordinat $(-6.877756,106.297666)$, dengan penyisihan amonium sebesar $89,40 \%$ dari 1 gram zeolit alam, dan $99,25 \%$ dari 5 gram zeolit alam.

b. Berdasarkan analisis XRD, zeolit alam Bayah dari lokasi 1, 2, 3, 4 memiliki jenis kristal mordenit, klinoptilolit, heulandit, dan quartz. Dari hasil analisis SEM dan EDS diperoleh morfologi zeolit alam Bayah dengan jenis kristal mordenit yang memiliki serat dan berbentuk seperti jarum-jarum, dan zeolit alam Bayah memiliki unsur $\mathrm{K}$ sebesar $4,24 \%$ dan Ca sebesar 1,89\%. Berdasarkan hasil analisis BET diperoleh luas permukaan zeolit alam Bayah sebesar $46 \mathrm{~m}^{2} / \mathrm{g}$, dan mempunyai nilai $\mathrm{R}$ (koefisien determinasi) sebesar 0.99 .

c. Model isoterm adsorpsi yang sesuai dengan adsorpsi amonium oleh zeolit alam Bayah adalah model isoterm Freundlich, yang memiliki nilai SSE sebesar 0,1677.

d. Model kinetika adsorpsi yang sesuai dengan adsorpsi amonium oleh zeolit alam Bayah adalah model persamaan pseudo-first order, yang memiliki nilai SSE sebesar 0,000154.

\section{PERSANTUNAN}

Penulis mengucapkan terima kasih kepada LPPM UNTIRTA yang telah memberikan pendanaan untuk penelitian ini dengan Kontrak No. 556/UN43.13/PM.01.01/2020.

\section{DAFTAR PUSTAKA}

1. Akbar, M. P. (2019). Pencemaran Sungai Di Indonesia. Republika .com. Jakarta

2. Widiastuti, N. Hongwei, W. Ha Ming Ang. Zhang, D. (2011). Removel Of Ammonium From Greywater Using natural Zeolite. Desalination, 277(3), 15-23.

3. Handayani, N. Widiastuti. N. (2009). Adsorpsi Ammonium $\left(\mathrm{NH}_{4}{ }^{+}\right)$Pada Zeolit Berkarbon dan Zeolit A yang Disintesis dari Abu Dasar Batubara Pt. Ipmomi Paiton dengan Metode Batch. Jurusan Kimia, Fak. MIPA Institut Teknologi Sepuluh Nopember. Surabaya.

4. Setyawan, N. M. Wardani, S. Kusumastuti, E. (2018). Arang Kulit Kacang Tanah Teraktivasi H3PO4 sebagai Adsorben Ion Logam Cu(II) dan Diimobilisasi dalam Bata Beton. Indonesian Journal of Chemical Science, 7(3) 262-269.

5. Dinas Energi dan Sumberdaya Mineral (2007). Potensi Sumberdaya Mineral Banten. Banten: Dinas Energy dan Sumberdaya Mineral.

6. Supandi, S. (2006). Karakterisasi Zeolit Alam dengan Metode Difraksi Sinar-X. Jurnal Zeolit Indonesia. 5(2), 52-68.

7. Ismettulloh, M., Gumelar F., Nuryoto N., Kurniawan, T. (2019). Modifikasi Zeolit Alam Bayah Menggunakan Asam dan Pengaplikasiannya Dalam Pengurangan Amonium Pada Kolam Ikan Bandeng. Jurnal Integrasi Proses, 8(1), 07-13

8. Diyanah, A. Bahri S., Nuryoto N., Kurniawan T. (2019). Modifikasi Zeolit Alam Bayah Menggunakan Basa Untuk Aplikasi Eliminasi Di Dalam Kolam Bandeng. Jurnal Integrasi Proses. 8(2), 57-64

9. Treacy, M. M. J., and Higgins J. B. (2007). Collection of Simulated XRD Powder Patterns for Zeolites: Elsevier

10. Hardjatmo, H. (1996). Study the Properties of Some Indonesia Natural Zeolites. One Day Seminar on Mineral Property and Utilization of Natural Zeolite. JSPS-BPPT.

11. Indarto, S. Suyadi, D. Setiawan, I. (2009). Genesa Zeolit daerah Cikancra, Cikalong, Kabupaten Tasikmalaya, Jawa Barat. Prosiding Pemaparan Hasil Penelitian Puslit Geoteknologi. Bandung. 
12. Purnamasari,I dan Prasetyo, D. (2010). Sintesis \& Karakterisasi ZSM-5 Mesopori serta Uji Aktivitas Katalitik pada Reaksi Esterifikasi Asam Lemak Stearin Kelapa Sawit: FMIPA ITS.

13. Metta, A. Ginting, B. S. Saputra, H. (2014). Sintesis ZSM-5 dari Coal Fly Ash (CFA) dengan Sumber Silika Penambah yang Berasal dari Abu Sekam Padi: Pengaruh Rasio $\mathrm{SiO}_{2} / \mathrm{Al}_{2} \mathrm{O}_{3}$ Terhadap Kristalinitas Produk. Jurnal Rekayasa Proses, 8(2), 62-68.

14. Atikah, S. W. (2017). Potensi Zeolit Alam Gunung Kidul Teraktivasi Sebagai Media Adsorben Pewarna Tekstil. Arena Tekstil, 32(1), 17-24.

15. Ekawati, R. Taslimah, T., Pardoyo, P. (2010). Pengaruh Aktifasi Zeolit Dengan $\mathrm{KMnO}_{4}$, $\mathrm{K}_{2} \mathrm{~S}_{2} \mathrm{O}_{8}$, dan $\mathrm{H}_{2} \mathrm{SO}_{4}$ Terhadap Adsorpsifitas Ion $\mathrm{Na}^{+}$dan $\mathrm{Mg}^{2+}$ Diujikan Pada Air Tanah Karimunjawa Blok I. Jurnal Sains dan Matematika, 18(4), 150-157.

16. Lestari, D.Y. (2010). Kajian modifikasi dan karakterisasi zeolit alam dari berbagai negara.
Prosiding Seminar Nasional Kimia dan Pendidikan Kimia.

17.Zakaria, A. Subariyah, I. Puramargapratala, Y. (2013). Karakterisasi Zeolit Alam Lampung Teraktivasi Asam Klorida dan Termodifikasi Asam Fosfat. Jurnal Teknologi Pengolahan Limbah, 16(3), 17-24.

18. Larasati, A., Notodarmojo, S. (2014). Kesetimbangan dan Kinetika Penyisihan Orthofosfat dari Dalam Air Dengan Metode Adsorpsi-Desorpsi. Jurnal Teknik Lingkungan, 20(1), 38-47.

19. Apriyanti, H. Candra, N., Elvinawati, E. (2018). Krakterisasi isoterm adsorpsi dari ion logam besi $(\mathrm{Fe})$ pada tanah di kota Bengkulu. Jurnal Pendidikan dan Ilmu Kimia, 2(1) 14-19.

20. Prasetya, A. Prihutami, P. Warisaura, A.D. Fahrurrozi, M. Petrus, H.T.B.M. (2020). Characteristic of $\mathrm{Hg}$ removal using zeolite adsorption and Echinodorus palaefolius phytoremediation in subsurface flow constructed wetland (SSF-CW) model, 8(3), 18. 